\title{
EVALUATION OF PATIENTS WITH SUBAXIAL CERVICAL FRACTURES BY THE NEW AOSPINE CLASSIFICATION
}

\author{
AVALIAÇÃO DE PACIENTES COM FRATURA CERVICAL SUBAXIAL POR MEIO DA NOVA \\ CLASSIFICAÇÃO AOSPINE
}

\section{EVALUACIÓN DE PACIENTES CON FRACTURA CERVICAL SUBAXIAL POR MEDIO DE LA NUEVA CLASIFICACIÓN AOSPINE}

\author{
Pedro Augusto Celestino de Oliveira, ${ }^{1}$ Alberto Gotfryd, ${ }^{1}$ Maria Fernanda Cafaro, ${ }^{1}$ Nelson Astur, ${ }^{1}$ Rodrigo Mendonça, ${ }^{1}$ Eduardo Hideyuki Akamine, ${ }^{1}$ \\ Osmar Avanzl, ${ }^{1}$ Robert Meves ${ }^{1}$ \\ 1. Irmandade da Santa Casa de Misericórdia de São Paulo, São Paulo, SP, Brazil.
}

\begin{abstract}
Objective: To evaluate the profile of patients with fracture and / or dislocation of the subaxial cervical spine using the new AOSpine classification and to correlate it with the trauma mechanism and the type of neurological deficit. Methods: Analyses were performed of the medical records of patients admitted to a tertiary hospital with fracture and / or subaxial cervical dislocation during the period from 2009 to 2016. For the evaluation of the association between the two categorical variables, the Chi-square test was used with a significance level of $\mathrm{p}<0.05$. Results: A total of 67 medical records were analyzed, in which a higher prevalence of type $\mathrm{C}$ fractures (49.3\%) was observed. The neurological subclassification N4 (35.8\%) was the most prevalent type found, followed by subtype N0 (26.9\%). Among the main injury mechanisms found, the most prevalent was the motorcycle accident (29.9\%). There was no statistically significant association between the injury mechanism and the AOSpine morphological classification ( $p>0.05$ ) or neurological deficit $(p>0.05)$. Conclusion: Cervical fractures of type $\mathrm{C}$, due to automobile accidents were the most prevalent. It was not possible to determine an association between the degree of neurological involvement and the morphology of the injury. Level of Evidence II; Retrospective study.
\end{abstract}

Keywords: Spinal Injuries; Spine; Spinal Fractures; Cervical Cord.

\section{RESUMO}

Objetivo: Avaliar o perfil dos pacientes com fratura e/ou luxação da coluna cervical subaxial por meio da nova classificação AOSpine e correlacionar com o mecanismo de trauma e o tipo de déficit neurológico. Métodos: Foram realizadas análises dos prontuários médicos dos pacientes admitidos em um hospital terciário com fratura e/ou luxação cervical subaxial entre o período de 2009 a 2016. Para a avaliação da associação entre as duas variáveis categóricas, utilizou-se o teste Qui-quadrado com nível de significância de $p<0,05$. Resultados: Foram analisados 67 prontuários, em que se obteve maior prevalência para as fraturas do tipo C (49,3\%). A subclassificação neurológica N4 (35,8\%) foi o tipo mais prevalente encontrado, seguido pelo subtipo No (26,9\%). Entre os principais mecanismos de lesão encontrados, o mais prevalente foi o acidente motociclístico (29,9\%). Não foi observada associação estatisticamente significativa entre o mecanismo de lesão com a classificação morfológica AOSpine $(p>0,05)$ ou com o déficit neurológico ( $p>0,05)$. Conclusão: As fraturas cervicais do tipo $C$, devido a acidentes automobilísticos, foram as mais prevalentes. Não foi possível obter associação entre o grau de acometimento neurológico e a morfologia da lesão. Nível de evidência II; Estudo Retrospectivo.

Descritores: Traumatismos da Coluna Vertebral; Coluna Vertebral; Fraturas da Coluna Vertebral; Medula Cervical.

\section{RESUMEN}

Objetivo: Evaluar el perfil de los pacientes con fractura y / o luxación de la columna cervical subaxial por medio de la nueva clasificación AOSpine y correlacionar con el mecanismo de trauma y el tipo de déficit neurológico. Métodos: Se realizaron análisis de los historiales médicos de los pacientes admitidos en un hospital terciario con fractura y/o luxación cervical subaxial entre el período de 2009 a 2016. Para la evaluación de la asociación entre dos variables categóricas, se utilizó el test Chi-cuadrado, con nivel de significancia de $p<0,05$. Resultados: Se analizaron 67 historiales, en que se obtuvo mayor prevalencia para las fracturas del tipo C (49,3\%). La subclasificación neurológica N4 (35,8\%) fue el tipo más prevalente encontrado, seguido del subtipo N0 (26,9\%). Entre los principales mecanismos de lesión encontrados, el más prevalente fue el accidente motociclístico (29,9\%). No se observó asociación estadísticamente significativa entre el mecanismo de lesión con la clasificación morfológica AOSpine ( $p>0,05)$ o con el déficit neurológico $(p>0,05)$. Conclusión: Las fracturas cervicales del tipo $C$, debido a accidentes automovilísticos, fueron las más prevalentes. No fue posible obtener asociación entre el grado de afectación neurológica y la morfología de la lesión. Nivel de evidencia II; Estudio retrospectivo.

Descriptores: Traumatismos Vertebrales; Columna Vertebral; Fracturas de la Columna Vertebral; Médula Cervical. 


\section{INTRODUCTION}

Injuries to the lower cervical spine (C3 to C7) are significantly serious since they often cause damage to the spinal cord leading to associated neurological deficit. Motor function sequelae from cervical spine trauma can be a definite comorbidity that mainly affects the young and active population. The prognosis for survival and functional recovery has improved and a decrease has been observed in the mortality rate from this type of injury (21.8\%). ${ }^{1-5}$

Several methods for the classification of traumatic injuries of the subaxial cervical spine have been proposed, but the complexity of these lesions makes it difficult to achieve an optimal system. One widely used classification is that proposed by the AO (Arbeitsgemeinschaft für Osteosynthesefragen), which has recently been updated in an attempt to increase the degree of concordance, based on modifiers for trauma mechanisms, involvement of the anterior and/or posterior spine, and degree of neurological injury. Thus, they were classified into three types (A, B and C), six subtypes and 22 modifiers. ${ }^{6-8}$ In this study, our hypothesis is that the more complex the modifier of the AOSpine fracture mechanism, the greater the degree of neurological impairment. To the authors' knowledge, there is no statistical association in the current literature between these two AOSpine classification modifiers.

The objective of this study is to assess the profile of patients with fracture and/or luxation of the subaxial cervical spine by means of the new updated AOSpine classification and to evaluate the associations between the trauma mechanisms and morphological fracture types.

\section{METHODS}

This is a retrospective study that analyzed the medical records and imaging examinations of patients admitted to the spine surgery service of a tertiary hospital, a benchmark for trauma care, diagnosed with fracture and/or subaxial cervical luxation, during the period from 2009 to 2016 and treated conservatively or surgically. The study was authorized by the Institutional Review Board (CAAE 64369716.6.0000.5479) and signing of the Informed Consent Form (ICF) was waived.

The inclusion criteria considered were patients of any age with a diagnosis of fracture and/or subaxial cervical luxation (C3 to C7) who had complete medical records, including a primary physical emergency or outpatient evaluation describing the trauma mechanisms, pre- and post-treatment neurological examinations, and radiography and computed tomography (CT) examinations of the cervical spine.

Patients with pathological fractures and victims of gunshot wounds were excluded from the study.

The included patients had their medical records evaluated and their imaging examinations classified using the recently modified AOSpine system for cervical spine injuries by two certified orthopedists with expertise in spine surgery. Analysis of the medical records was based on extraction of complete epidemiological data, such as age at the time of the traumatic event, sex, trauma mechanism and degree of neurological deficit upon admission to the hospital.

The cervical injuries of the included patients were classified by the AOSpine system proposed in 2016. ${ }^{7}$ The new AOSpine classification is divided into three main types: $A, B$ and $C$. Type A fractures are related to the mechanism of compression, while type $B$ are related to distraction of the cervical vertebrae. Type $\mathrm{C}$ injuries result from a complex mechanism where there is loss of alignment (luxation) at the cervical level involved (Table 1).

In addition, the classification allows the evaluation of facet joint compromise $(F)$, subdivided into 4 levels (Table 2), and neurological impairment $(\mathrm{N})$, ranging from 0 to 4 (Table 2). There are also modifiers that indicate conditions relevant to the patients, being subdivided into 4 levels:

- M1: the bone structures are theoretically stable, but there is an important potentially unstable ligament injury

- M2: there is substantial disc herniation at the compromised level

- M3: fractures that affect patients with metabolic disorders, such
Table 1. AOSpine classification for subaxial cervical fractures (C3-C7).

\begin{tabular}{|c|c|}
\hline \multirow{6}{*}{$\begin{array}{l}\text { Type A - } \\
\text { Compression }\end{array}$} & Subtypes \\
\hline & A0 - Non-structural fractures \\
\hline & A1 - Impaction \\
\hline & A2 - Split (separation) \\
\hline & A3 - Partial burst \\
\hline & A4 - Total burst \\
\hline \multirow{3}{*}{$\begin{array}{l}\text { Type B - } \\
\text { Distraction }\end{array}$} & $\begin{array}{l}\text { B1 - Posterior tension band injury, where the line of the } \\
\text { fracture only passes through bone structures }\end{array}$ \\
\hline & $\begin{array}{l}\text { B2 - Total posterior tension band injury involving capsulo- } \\
\text { ligamentous structures together with vertebral body and } \\
\text { disc and/or facet joint }\end{array}$ \\
\hline & B3 - Injury of the anterior tension band \\
\hline $\begin{array}{l}\text { Type C - } \\
\text { Translation }\end{array}$ & $\begin{array}{l}\mathrm{C} \text { - Injuries with dislocation or translation of a vertebral } \\
\text { body in relation to another adjacent one in any direction }\end{array}$ \\
\hline
\end{tabular}

Table 2. AOSpine Classification - Facet joint compromise and neurological impairment.

\begin{tabular}{|c|c|}
\hline \multirow{5}{*}{$\begin{array}{l}\text { Facet joint injury/ } \\
\text { compromise }\end{array}$} & Subtypes \\
\hline & F1 - Facet joint injuries/compromises without deviations \\
\hline & $\begin{array}{l}\text { F2 - Facet joint injuries/compromises with potential } \\
\text { instability. Deviations greater than } 1 \mathrm{~cm} \text { and/or more } \\
\text { than } 40 \% \text { of the lateral mass impairment. }\end{array}$ \\
\hline & $\begin{array}{l}\text { F3 - Floating lateral mass separated from the pedicle } \\
\text { and the lamina }\end{array}$ \\
\hline & F4 - Luxations in relation to the adjacent vertebrae \\
\hline \multirow{6}{*}{ Neurological status } & NO - Neurologically intact \\
\hline & N1 - Transient neurological deficit \\
\hline & N2 - Nerve root deficit \\
\hline & N3 - Incomplete neurological injury \\
\hline & N4 - Complete neurological injury \\
\hline & NX - When neurological evaluation was not possible \\
\hline
\end{tabular}

as posterior longitudinal ligament ossification, ankylosing spondylitis, among others

- M4: injuries of the vertebral artery

Statistical analysis consisted of evaluation by means of mean and standard deviation for continuous variables and absolute and relative frequencies in cases of categorical variables. For evaluation of the association between two categorical variables the chi-squared test was used with a significance level of $<0.05$. Data analysis was conducted using SPSS Statistics 21 statistical software.

\section{RESULTS}

Initially, 77 patients were identified who had been hospitalized between 2009 and 2016 with a diagnosis of fracture and/or luxation of the subaxial cervical spine (C3-C7). Of these, 10 were excluded for not meeting the established inclusion criteria. At the end, 67 patients were included in the study, $82.1 \%$ men and $17.9 \%$ women with a mean age of 34.7 years (standard deviation \pm 15.9 ).

Type C lesions were the most prevalent (49.3\%), followed by type A (38.8\%) and finally, type B (11.9\%) (Table 3).

In terms of the classification subtypes (A0, A1, A2, A3, A4, B1, $B 2, B 3)$, we found that in type $A$ the highest prevalence of subtype A2 (34.6\%), followed by subtype A4 (30.8\%). In type B, the subtype with the highest prevalence was B2 (75\%), followed by subtype B1 (25\%) (Table 4).

Neurological subclassification N4 (35.8\%) was the most prevalent, followed by subtypes N0 (26.9\%) and N3 (23.9\%). In relation to the modifier of neurological compromise, grouped by the main types of subaxial cervical fractures (A, B and C), subtype N0 followed by N3, at $42.3 \%$ and $26.9 \%$, respectively, were the most prevalent in type A. In type B, subclassification N3 was the most prevalent at 50\%, followed by $\mathrm{N} 4$ at $25 \%$. In type $\mathrm{C}$, the most prevalent subclassification was N4 (48.5\%), followed by N0 (18.2\%) (Table 5). No statistically significant 
association was observed between the AOSpine morphological classification (A, B, and $C$ ) and the status of neurological compromise (Chi-squared $=15.174, p=0.056$ ) (Table 5).

Regarding the degree of facet joint injury and impairment (F1, F2, F3 and F4) within each main type, we observed that for type A the principal subclassification was F1 (60\%), followed by F2 (30\%), all cases being unilateral. Type B presented F1 (62.5\%) as its principal subclassification, with no bilateral facet joint fractures, while the main subclassification found for type $\mathrm{C}$ fractures was F2 (66.7\%), with four cases with bilateral facet joint fractures for subclassification F2 and one for F3 (Table 6).

In terms of the most affected cervical level by type of fracture, alone or in pairs, we observed that for type $A$, involvement of $\mathrm{C} 5$ (38.5\%) was prevalent, followed by level C6 (19.2\%). Type B had the greatest involvement at level C5 (37.5\%), in isolated form, followed by $\mathrm{C} 7$ (25\%). Type $\mathrm{C}$ showed greater involvement in interval between C5-C6 (51.5\%) (Table 7).

Among the main injury mechanisms found, the most prevalent was motorcycle accidents (29.9\%), followed by episodes of falls (28.4\%) (Table 8 ). No statistically significant association was observed between the injury mechanism and the AOSpine morphological classification (A, B and C) (Chi-squared $=7.797$, $\mathrm{p}=0.253$ ) or with the neurological impairment status (Chi-squared $=$ $6.618, p=0.882$ ).

When considering the intra-articular movements of the adjacent subaxial cervical vertebral pairs involved in the type $\mathrm{C}$ classification, the lower vertebrae at these levels presented fractures that were divided into AOSpine classification A subtypes.

Table 3. Classification by AOSpine types.

\begin{tabular}{c|c|c}
\hline & Frequency & Percentage (\%) \\
\hline Type A & 26 & $(38.8 \%)$ \\
\hline Type B & 8 & $(11.9 \%)$ \\
\hline Type C & 33 & $(49.3 \%)$ \\
\hline Total & 67 & $(100.0 \%)$ \\
\hline
\end{tabular}

Table 4. AOSpine classification and its respective subtypes.

\begin{tabular}{c|c|c|c|c|c|c|c}
\hline \multicolumn{2}{c|}{} & \multicolumn{6}{c|}{ AOSpine Classification } \\
\hline \multicolumn{3}{c}{} & \multicolumn{2}{|c|}{ A } & \multicolumn{2}{|c|}{ B } & \multicolumn{2}{c}{ C } \\
\hline \multirow{4}{*}{$\begin{array}{c}\text { AOSpine } \\
\text { Subtypes }\end{array}$} & 0 & 1 & $(3.8 \%)$ & 0 & $(0.0 \%)$ & 0 & $(0.0 \%)$ \\
\cline { 2 - 9 } & 1 & 5 & $(19.2 \%)$ & 2 & $(25.0 \%)$ & 0 & $(0.0 \%)$ \\
\cline { 2 - 9 } & 2 & 9 & $(34.6 \%)$ & 6 & $(75.0 \%)$ & 0 & $(0.0 \%)$ \\
\cline { 2 - 9 } & 3 & 3 & $(11.5 \%)$ & 0 & $(0.0 \%)$ & 0 & $(0.0 \%)$ \\
\cline { 2 - 9 } & 4 & 8 & $(30.8 \%)$ & 0 & $(0.0 \%)$ & 0 & $(0.0 \%)$ \\
\hline
\end{tabular}

Table 5. Morphological classification of the fractures and association with neurological status.

\begin{tabular}{c|c|c|c|c}
\hline \multicolumn{2}{c|}{} & Frequency & Percentage (\%) & P Value \\
\hline \multirow{4}{*}{$\begin{array}{c}\text { Neurological status } \\
\text { classification }\end{array}$} & 0 & 18 & $(26.9 \%)$ & \\
\cline { 2 - 4 } & 1 & 3 & $(4.5 \%)$ & \\
\cline { 2 - 4 } & 2 & 6 & $(9.0 \%)$ & \multirow{3}{*}{$\mathrm{P}>0.05$} \\
\cline { 2 - 4 } & 3 & 16 & $(23.9 \%)$ & \\
\cline { 2 - 4 } & 4 & 24 & $(35.8 \%)$ & \\
\cline { 2 - 4 } & Total & 67 & $(100 \%)$ & \\
\hline
\end{tabular}

* Test of association (Chi-squared).

Table 6. AOSpine Classification by facet joint injury/compromise.

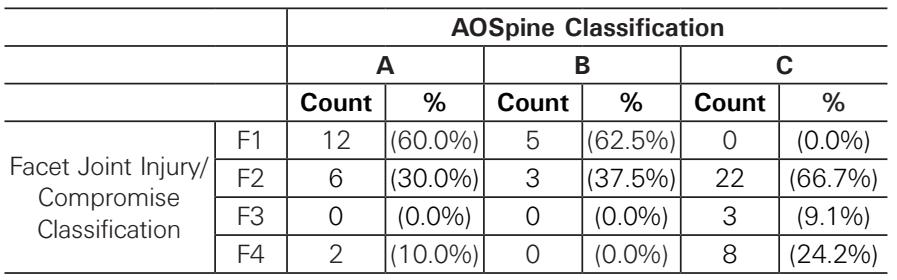

Thus, levels C6-C7 and C5-C6 showed greater involvement of the lower vertebrae in subtypes A1 and A2. Level C3-C4 was more affected by type A1 fractures, level C4-C5 by subtype A2 fractures, and level C2-C3 had greater lower vertebral involvement classified as A3 (Table 9).

Table 7. Distribution of cervical levels affected by AOSpine classification.

\begin{tabular}{|c|c|c|c|c|c|c|c|}
\hline & \multicolumn{6}{|c|}{ AOSpine Classification } \\
\hline & & \multicolumn{2}{|r|}{ A } & \multicolumn{2}{|c|}{ B } & \multicolumn{2}{|r|}{ C } \\
\hline & & Count & (\%) & Count & (\%) & Count & (\%) \\
\hline \multirow{11}{*}{$\begin{array}{c}\text { Cervical } \\
\text { Levels }\end{array}$} & C6-C7 & 0 & $(0.0 \%)$ & 0 & $(0.0 \%)$ & 5 & $(15.2 \%)$ \\
\hline & C7 & 3 & (11.5\%) & 2 & (25.0\%) & 0 & $(0.0 \%)$ \\
\hline & C5-C6 & 0 & $(0.0 \%)$ & 0 & $(0.0 \%)$ & 17 & $(51.5 \%)$ \\
\hline & C3-C4 & 0 & $(0.0 \%)$ & 0 & $(0.0 \%)$ & 2 & $(6.1 \%)$ \\
\hline & $\mathrm{C} 4-\mathrm{C5}$ & 0 & $(0.0 \%)$ & 0 & $(0.0 \%)$ & 2 & $(6.1 \%)$ \\
\hline & $\mathrm{C} 2-\mathrm{C} 3$ & 0 & $(0.0 \%)$ & 0 & $(0.0 \%)$ & 1 & $(3.0 \%)$ \\
\hline & $\mathrm{C} 4$ & 3 & $(11.5 \%)$ & 2 & $(25.0 \%)$ & 2 & $(6.1 \%)$ \\
\hline & $\mathrm{C} 3$ & 4 & $(15.4 \%)$ & 0 & $(0.0 \%)$ & 1 & $(3.0 \%)$ \\
\hline & $\mathrm{C5}$ & 10 & $(38.5 \%)$ & 3 & $(37.5 \%)$ & 2 & $(6.1 \%)$ \\
\hline & C6 & 5 & $(19.2 \%)$ & 1 & $(12.5 \%)$ & 1 & $(3.0 \%)$ \\
\hline & C8 & 1 & (3.8\%) & 0 & $(0.0 \%)$ & 0 & $(0.0 \%)$ \\
\hline
\end{tabular}

Table 8. Distribution of injury mechanisms.

\begin{tabular}{c|c|c}
\hline Injury mechanisms & Frequency & Percentage (\%) \\
\hline Car accident & 18 & $(26.9 \%)$ \\
\hline Fall & 19 & $(28.4 \%)$ \\
\hline Motorcycle accident & 20 & $(29.9 \%)$ \\
\hline Diving & 10 & $(14.9 \%)$ \\
\hline Total & 67 & $(100.0 \%)$ \\
\hline
\end{tabular}

\section{DISCUSSION}

Traumatic injuries of the cervical spine are being increasingly studied, since, whether accompanied by neurological changes or not, they have high rates of severe functional impairment, which may lead to the death of these patients in many cases. According to Oliveira and Avanzi, there may be a high mortality rate during hospitalization, the first ten days being the period of greatest risk. ${ }^{2}$ Thus, great importance is given to the ability to make rapid decisions for these types of patients, where many of the interventions are based on well-estbablished classifications, as is the case with AOSpine. ${ }^{9}$

The AOSpine classification is considered the main one to be used in cervical fractures. Studies involving comparisons and degrees of reproducibility with other classifications, favor the subdivision presented by AOSpine. ${ }^{7,9}$ The Allen classification, developed in 1982, has traditional relevance among orthopedists. The inter- and intra-evaluator comparison between the subdivisions proposed by both has shown a preference for the use of the AOSpine classification, thus being suggested as the main one to be used. ${ }^{9-11}$ As a possible limitation of this study, the study by Jorge et al. suggests that, when fractures in the low cervical spine are involved, the degree of inter and intra-evaluator reproducibility turned out to be lower, justified by its recent use in these injuries. ${ }^{12}$

As regards the trauma mechanism, Koch et al. concluded that in a sample of 502 cases, episodes of falls and traffic accidents were the main ones responsible for this type of injury, ${ }^{10}$ data similar to those found in the present study. Vasconcelos and Riberto, like the study that reported more than $50 \%$ of the injuries involving car and motorcycle accents, also indicated this mechanism as the principal cause of possible fractures at cervical levels. ${ }^{11}$

In our study, there was facet joint involvement in approximately $90 \%$ of the cases, a fact that indicates high energy trauma. ${ }^{7}$ Because this component plays a fundamental role as an articular stabilizer, mainly bracing against rotational and axial forces, the long-term evolution and prognosis, approximately one year after injury, is worse as compared to fractures without involvement of these structures. ${ }^{7,13}$ 
Table 9. Distribution of the AOSpine classification for lower cervical vertebrae with type C fractures.

\begin{tabular}{|c|c|c|c|c|c|c|c|c|c|}
\hline & & \multicolumn{8}{|c|}{ AOSpine Classification } \\
\hline & & \multicolumn{2}{|c|}{ A1 } & \multicolumn{2}{|c|}{ A2 } & \multicolumn{2}{|c|}{ A3 } & \multicolumn{2}{|c|}{ A4 } \\
\hline \multirow{4}{*}{$\begin{array}{c}\text { Cervical } \\
\text { Levels }\end{array}$} & C6-C7 & 2 & (22.2\%) & 2 & $(22.2 \%)$ & 1 & $(16.7 \%)$ & 0 & $(0.0 \%)$ \\
\hline & C3-C4 & 2 & (22.2\%) & 0 & $(0.0 \%)$ & 0 & $(0.0 \%)$ & 0 & $(0.0 \%)$ \\
\hline & C4-C5 & 0 & $(0.0 \%)$ & 2 & $(22.2 \%)$ & 0 & $(0.0 \%)$ & 0 & $(0.0 \%)$ \\
\hline & $\mathrm{C} 2-\mathrm{C} 3$ & 0 & $(0.0 \%)$ & 0 & $(0.0 \%)$ & 1 & $(16.7 \%)$ & 0 & $(0.0 \%)$ \\
\hline
\end{tabular}

The association between the fracture type classifications at the morphological and neurological levels, although not presenting any statistically significant values, showed greater neural impairment of subtype N4 in type C fractures. This type of fracture, considered potentially more "explosive", has a complex action as its main injury mechanism, associated with the loss of alignment (luxation) between the cervical levels involved, thus being one of the main reasons behind the greater degrees of neurological impairment of this type versus the others. ${ }^{7-9}$

Limitations of this study are the small number of cases, making obtaining the previously selected variables difficult, and the procedures established for retrospective analyses of the selected documents.

\section{CONCLUSION}

Type C cervical fractures in patients who were victims of automobile accidents were the most prevalent injuries in the medical records analyzed using the AOSpine classification. There was no association between these variables and the degree of neurological impairment.

All authors declare no potential conflict of interest related to this article.

CONTRIBUTION OF THE AUTHORS: Each author made significant individual contributions to this manuscript. PACO (0000-0001-7536-806X) ${ }^{\star}$, AG $(0000-0003-3143-2845)^{\star}$, MFC (0000-0002-2823-8534)*, NA (0000-0002-2608-2118)*, RM (0000-0003-1486-5569)*, EHA (0000-0002-0323-2830* ${ }^{\star}$, OA $(0000-0003-2462-6422)^{*}$ and RM (0000-0002-8695-3982)* actively participated in data collection and the discussion of the results and contributed to the review and approval of the final version of the manuscript. *ORCID (Open Researcher and Contributor ID).

\section{REFERENCES}

1. Riska EB, Von Bonsdorff H, Hakkinen S, Jaroma H, Kiviluoto O, Paavilainen T. Primary operative fixation of long bone fractures in patients with multiple injuries. J Trauma. 1977:17(2):111-21.

2. Oliveira AR, Avanzi O. Estudo sobre a mortalidade de pacientes com fratura da coluna cervical durante o período de hospitalização. Rev Bras Ortop. 2002:37(3):89-96.

3. McGrory B, Klassen R, Chao E, Staeheli J, Weaver A. Acute fractures and dislocations of the cervical spine in children and adolescents. J Bone Joint Surg Am. 1993:75(7):988-95.

4. Sherk HH, Nicholson JT, Chung S. Fractures of the odontoid process in young children. J Bone Joint Surg Am. 1978;60(7):921-4.

5. Alker Jr G, Oh YS, Leslie E. High cervical spine and craniocervical junction injuries in fatal traffic accidents: a radiological study. Orthop Clin North Am. 1978;9(4):1003-10.

6. DeVivo MJ. Causes and costs of spinal cord injury in the United States. Spinal Cord. 1997:35(12):809-13

7. Vaccaro AR, Koerner JD, Radcliff KE, Oner FC, Reinhold M, Schnake KJ, et al AOSpine subaxial cervical spine injury classification system. Eur Spine J. 2016;25(7):2173-84.
8. Moore TA, Vaccaro AR, Anderson PA. Classification of lower cervical spine injuries. Spine (Phila Pa 1976). 2006;31(11 Suppl):S37-43.

9. Urrutia J, Zamora T, Campos M, Yurac R, Palma J, Mobarec S, et al. A comparative agreement evaluation of two subaxial cervical spine injury classification systems: the AOSpine and the Allen and Ferguson schemes. Eur Spine J. 2016;25(7):2185-92.

10. Koch A, Graells X, Zaninelli EM. Epidemiologia de fraturas da coluna de acordo com o mecanismo de trauma: análise de 502 casos. Coluna/Columna. 2007:6(1):18-23.

11. Vasconcelos ECLM, Riberto M. Caracterização clínica e das situaç̃es de fratura da coluna vertebral no município de Ribeirão Preto, propostas para um programa de prevenção do trauma raquimedular. Coluna/Columna. 2011:10(1):40-3.

12. Jorge RM, Jorge GM, Karoleski MS. Reprodutibilidade da classificação de Allen versus classificação AO para fraturas da coluna cervical baixa. Coluna/Columna. 2008;7(4):340-3.

13. Nadeau M, McLachlin SD, Bailey SI, Gurr KR, Dunning CE, Bailey CS. A biomechanical assessment of soft-tissue damage in the cervical spine following a unilateral facet injury. J Bone Joint Surg Am. 2012;94(21):e156. 